\title{
Obra de arte e filosofia: uma leitura de Franz Kafka a partir de Theodor Adorno
}

\author{
Work of art and philosophy: Franz Kafka, a reading based on Theodor \\ Adorno
}

http://dx.doi.org/10.5007/2178-4582.2017v51n1p003

Pedro Savi Neto

Pontificia Universidade Católica do Rio Grande do Sul, Porto Alegre/RS, Brasil

\begin{abstract}
Trata-se de uma pesquisa teórica conduzida a partir de uma releitura do pensamento do filósofo Theodor Adorno, integrante da primeira geração da Escola de Frankfurt, com ênfase no caráter de crítica social de seu pensamento, em movimento dialético com a literatura do escritor Franz Kafka, valendo-se de obras de ambos, com especial atenção às referências diretas do filósofo ao escritor, recorrendo-se, eventualmente, a comentadores. A partir de uma análise da relação entre filosofia e obra de arte no pensamento de Adorno, objetiva-se evidenciar que tanto o pensamento do filósofo quanto a literatura de Kafka são marcados pela crítica de uma sociedade administrada pela racionalidade iluminista que se converte em violência contra o próprio sujeito. Embora distintas, filosofia e obra de arte se complementam como resistência à massificação cultural, cabendo à primeira interpretar a segunda.

Palavras-chave: filosofia e obra de arte; sociedade administrada e dialética negativa; Theodor Adorno e Franz Kafka.
\end{abstract}

This is a theoretical research conducted from rereading the thought of the philosopher Theodor Adorno, a member of the first generation of the Frankfurt School, with emphasis on the character of social criticism of his thinking in dialectical movement by reading Franz Kafka, making use of works of both authors, with special attention to direct references of the philosopher about the writer's work, using up eventually commentators. From an analysis of the relationship between philosophy and works of art as thought by Adorno, the goal is to show that both the thought of the philosopher and Kafka's literature are marked by criticism of a society managed by Enlightenment rationality, which converts to violence against the subject himself. Although distinct, philosophy and works of art complement each other as resistance to cultural mass, while the first interprets the second.

Keywords: philosophy and work of art; administered society and negative dialectics; Theodor Adorno and Franz Kafka.

\section{Considerações iniciais}

Trata-se de uma pesquisa teórica conduzida a partir de uma releitura do pensamento do filósofo Theodor Adorno (1903-1969), integrante da primeira geração da Escola de Frankfurt ${ }^{1}$, com ênfase no caráter de crítica social de seu pensamento, em movimento dialético com a literatura do escritor Franz Kafka (1883-1924), valendo-se de obras de ambos, com especial atenção às referências diretas do filósofo ao escritor e recorrendo-se, eventualmente, a comentadores.

A partir de uma análise da relação entre filosofia e obra de arte no pensamento de Adorno, objetiva-se evidenciar que tanto o pensamento

1 O termo se refere a um grupo de pensadores de orientação neomarxista, associado com o Instituto para Pesquisa Social da Universidade de Frankfurt. 
do filósofo quanto a literatura de Kafka são marcados pela crítica de uma sociedade administrada pela racionalidade iluminista que se converte em violência contra o próprio sujeito.

Iniciaremos pela análise das categorias adornianas necessárias para fundamentar o objetivo referido, prosseguindo com uma análise dos principais elementos da obra de Kafka, para, então, lançar mão de ilustrações literárias ao pensamento do filósofo que justifiquem o encadeamento proposto.

\section{Racionalidade instrumental e sociedade administrada}

Uma das referências fundamentais para este estudo sobre a filosofia de Adorno é a sua obra clássica, escrita em parceria com Max Horkheimer, durante a década de 1940, Dialética do esclarecimento (1985), a qual possui como crítica central a instrumentalização da razão iluminista que pretendia conhecer o mundo, livrando o ser humano de uma explicação mitológia da natureza. Referido procedimento se opera tendo como fundamento o pensamento matemático que marca a ciência do período moderno. Nesse sentido, Adorno e Horkheimer afirmam que "O que não se submete ao critério da calculabilidade e da utilidade torna-se suspeito para o esclarecimento" (1985, p. 19).

Nesse processo, a relação que Adorno estabelece entre mito e razão parte da ideia de que, com a racionalidade esclarecida, o ser humano passa a acreditar que a chave para o entendimento da totalidade está nele mesmo e em sua capacidade de racionalização, eliminando o desconhecido que é fonte de medo e angústia. Toda diferença é reduzida ao poder racional do sujeito. $\mathrm{O}$ objeto se sobsome de algum modo no sujeito, determinando o trajeto da desmitologização. A subjetivação da razão faz o ser humano acreditar na sua posição de senhor absoluto do mundo, fazendo surgir a "ideologia da razão" por detrás do esclarecimento do mundo.

A crítica dos dois filósofos frankfurtianos evidencia que esse mesmo movimento de pretenso esclarecimento mantém uma profunda semelhança ao mito, na medida em que contém em seu interior uma estrutura de conhecimento atrelada à repetição. As equações, fórmulas e conceitos somente se consolidam pela sua possibilidade de repetição.

O mito converte-se em esclarecimento, e a natureza em mera objetividade. O preço que os homens pagam pelo aumento de seu poder é a alienação daquilo sobre o que exercem o poder. $\mathrm{O}$ esclarecimento comporta-se com as coisas como o ditador se comporta com os homens. Este conhece-os na medida em que pode manipulá-los. O homem de ciência conhece as coisas na medida em que pode fazê-las. É assim que seu em-si torna para- 
ele. Nessa metamorfose, a essência das coisas revela-se como sempre a mesma, como substrato da dominação. (ADORNO; HORKHEIMER, 1985, p. 21).

Na Dialética do esclarecimento restam claramente evidenciados dois movimentos do esclarecimento: um processo que desencanta a natureza, pretendendo ultrapassar a construção mitológica, na qual o homem é visto como amedrontado por forças externas divinizadas; mas, por outro lado, o movimento da autonomia frente a estas ameaças externas que acaba se transformando em uma autopreservação selvagem, fazendo com que o controle sobre a natureza externa regrida a uma violência introjetada que cria uma série de limitações e repressões que restringem as pretensões de liberdade da humanidade. Ou seja, Adorno e Horkheimer afirmam que o esforço que o ser humano faz para fugir ao domínio da natureza se volta contra ele próprio; todo esse esforço de rompimento da dominação gera dominação, contendo traços de regressividade.

A dominação da natureza, portanto, se faz possível por uma espécie de violência exercida contra aquele que a desencanta, pois, ao se desfazer da compreensão mitológica do mundo, o ser humano desfaz-se de si próprio, violenta a sua história e a sua primeira tentativa de esclarecer o mundo. Todo esse processo ocorre com agravantes: na explicação mitológica não havia o elemento de coisificação da natureza e de sua infinita possibilidade de intercambialidade universal. Para a ciência, baseada na aplicação irrestrita, a relação entre o sujeito e o objeto não se faz mais necessária; mais do que desnecessária, a relação direta com o objeto pode comprometer a repetibilidade do experimento, o qual passa a depender do distanciamento progressivo entre sujeito e objeto para afirmar-se como objetividade. Todos esses elementos passam a conferir ao ser humano a tão sonhada possibilidade de intervir sem limites na natureza tornada objeto.

Tal questão se torna ainda mais grave para Adorno, adquirindo especial importância em sua obra, quando percebe que a sua argumentação conduz à conclusão de que a natureza, transformada em mero objeto que deve servir aos desígnios humanos, é composta por animais e seres humanos que também se tornam elementos dessa mesma lógica. Adorno avança por esse raciocínio argumentando que as fronteiras entre o humano e aquilo que não é humano tornam-se nebulosas, importando, apenas, seu caráter de dominação.

Na obra Minima Moralia (1993), Adorno argumenta que a dominação do humano pelo humano começa por submeter aqueles mais ligados à natureza. Como exemplo, ele analisa a dominação masculina sobre a mulher na sociedade burguesa, enquanto esta representa o sexo frágil, imagem da natureza. 
Aquela que, quando sangra, se sente como uma ferida sabe mais de si do que uma mulher que se acha uma flor, por que ao seu marido assim convém. A mentira não reside só em dizer que a natureza se afirma onde ela sofre e se acomoda; o que na civilização se entende por natureza é, na sua substância, o mais afastado de toda a natureza, o puro converter-se a si mesmo em objecto. O tipo de feminilidade baseado no instinto constitui sempre aquilo a que cada mulher, com toda a violência - com violência masculina - se deve forçar: as mulherzinhas são os homenzinhos. Basta apenas observar, sob o efeito dos ciúmes, como tais mulheres femininas dispõem da sua feminilidade, como a acentuam segundo a sua conveniência, como fazem brilhar os seus olhos e se servem do seu temperamento, para saber quão escassa relação há nisso com um inconsciente resguardado e não estropiado pelo intelecto. A sua integridade e pureza são obra do eu, da censura, do intelecto, e é por isso que a mulher se adapta com tão poucos conflitos ao princípio de realidade da ordem racional. (ADORNO, 1993, p. 84-85).

Tal linha argumentativa empresta elementos para a compreensão da questão adorniana da barbárie que acompanha o chamado progresso e que teve como seu ápice Auschwitz. Para Adorno, a eliminação do outro é decorrência desse caminho de dominação da natureza percorrido pela razão iluminista, percurso que teria como fato histórico extremo o holocausto judeu, engendrado justamente a partir dessa ideia de forçosa associação dos seres humanos dominados à natureza.

Nos antissemitas, talvez o esquematismo social da percepção esteja configurado de tal modo que não conseguem ver os Judeus como homens. A tão ouvida afirmação de que os selvagens, os negros ou os Japoneses parecem animais, porventura macacos, contém já a chave do pogrom. A sua possibilidade fica já decidida no momento em que o olho de um animal mortalmente ferido dá com o homem. A obstinação com que este desvia de si esse olhar - "é apenas um animal" repete-se sem excepção nas crueldades infligidas aos homens, nas quais os executores têm continuamente de se persuadir do "é só um animal", porque já nisso não podiam acreditar nem sequer no animal. (ADORNO, 1993, p. 95).

A massificação e administração da sociedade é entendida a partir daí. Adorno vai mais adiante com a sua argumentação e se debruça sobre à capacidade do ser humano de suportar e, até, de se submeter a essa dominação. Evidencia que, em princípio, um ego fortalecido seria mais apto para resistir à administração. Contudo, o indivíduo dominado, sujeito às imposições do meio, subjugado pelo todo social, sequer tem motivos capazes de justificar 
um ego fortalecido. Para suportar essa dor, ele acaba se alienando no todo e substituindo o prazer ausente em sua vida por uma identificação/admiração pelo poder do dominador. O fortalecimento do ego afigurar-se-ia como importante ferramenta de resistência, pois o Eu só se afirma na medida em que consegue se delimitar com relação ao todo, dominando primeiro a natureza interna para, depois, escapar ao controle do meio.

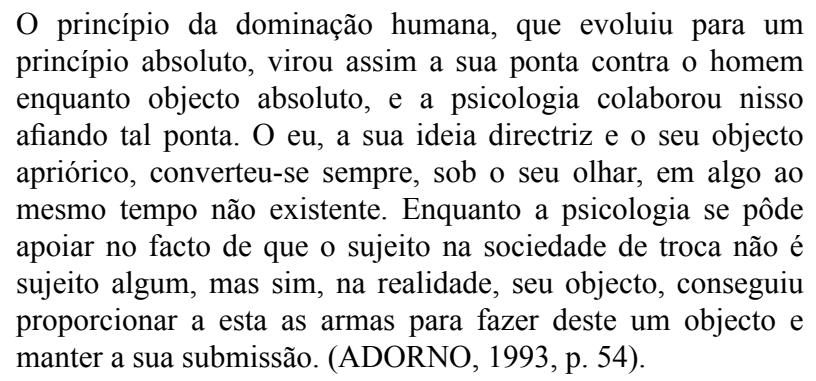

Esse procedimento de racionalização que surge como promessa de libertação do ser humano e que logo se converte em mecanismo de dominação da natureza e do próprio ser humano serve de fundamento à noção fundamental do pensamento adorniano de sociedade administrada. Tal linha de argumentação central da obra Minima moralia se faz presente na filosofia adorniana desde a Dialética do esclarecimento, acompanhando a integralidade da obra de Adorno.

Nesse contexto de administração da sociedade para a dominação do ser humano, restaria para a cultura a tarefa de participar da autêntica emancipação humana pela razão. Contudo, seu obstáculo é que nada escapa à razão instrumental, pensada e instalada também no âmbito da produção cultural, assumindo os traços de totalidade sufocante.

$\mathrm{Na}$ Dialética do esclarecimento, seus autores argumentam que a administração da sociedade se projeta sobre a produção cultural na forma daquilo que cunharam com a conhecida expressão indústria cultural, como sendo um dos mecanismos da razão instrumentalizada para manter a dominação sobre as massas também a partir da cultura, funcionando como mais uma das formas de controle. Seria mais um mecanismo de pressão pela identidade, mediante uma arte marcada pela produção em série, indiferenciação, ausência de abertura ao diálogo e pelo seu caráter de mero entretenimento.

O termo indústria não foi escolhido sem a devida reflexão sobre o seu significado: queria dizer justamente a produção de mercadorias. Adorno e Horkheimer comparam a produção cultura à produção de veículos: 
A diferença entre a série Chrysler e a série da General Motors é no fundo uma distinção ilusória, como já sabe toda criança interessada em modelos de automóveis. As vantagens e desvantagens que os conhecedores discutem servem apenas para perpetuar a ilusão da concorrência e da possibilidade de escolha.

O mesmo se passa com as produções da Warner Brothers e da Metro Goldwyn Mayer. Até mesmo as diferenças entre os modelos mais caros e mais baratos da mesma firma se reduzem cada vez mais: nos automóveis, elas se reduzem ao número de cilindros, capacidade, novidade dos gadgets, nos filmes ao número de estrelas, à exuberância técnica, do trabalho e do equipamento, e ao emprego de fórmulas psicológicas mais recentes. (ADORNO; HORKHEIMER 1985, p. 102).

Para os pensadores, o cinema se afigurava na forma mais flagrante desse mecanismo, pois permitiria que indústria cultural assumisse sua característica narcisista, vendendo aos seus consumidores o prazer de representá-los. Mantendo, mais uma vez, a lógica da identidade, de razão já pensada, na medida em que funcionaria como um mecanismo de anulação do autêntico exercício racional.

A sociedade administrada pela racionalidade instrumental, dessa maneira, lograva êxito em associar o lazer ao mero entretenimento, no qual não se fazia necessária qualquer atividade racional. Tudo isso era garantido mediante a representação paupérrima da realidade: toda produção cultural limitava-se a enquadramentos simples, como "mocinho" e "bandido", bom e mau, final feliz ou triste, que determinariam o estabelecimento de modelos mentais semelhantemente simplificados a seus consumidores.

No contexto de uma razão instrumentalizada totalizadora, não cumpridora com a sua promessa de civilização, surge a questão fundamental do pensamento adorniano: como é possível que a humanidade livrada do mito pela teoria tradicional, ao invés de "entrar em um estado verdadeiramente humano, está se afundando em uma nova espécie de barbárie?" (ADORNO; HORKHEIMER, 1985 , p. 11). Tal questão deve ser articulada dialeticamente em conjunto com outra conhecida frase de Adorno (apud SOUZA, 2004, p. 120) de que "Nenhuma história universal leva da selvageria ao humanismo, mas há uma história universal que leva da funda à bomba atômica". Isso também representa que Adorno não encarou a história a partir de sua dimensão cronológica, enquanto um caminho linear para o progresso científico-tecnológico do ser humano, alavancado a partir do projeto iluminista de esclarecimento do mundo; mas, sim, a partir da ideia de que a barbárie sempre esteve presente na história da humanidade e ainda não conseguimos superá-la. 
A filosofia exerce o seu papel de resistência enquanto "comentário e crítica" (SELIGMANN-SILVA, 2009, p. 11), assumindo, em Adorno, a tarefa de ser o local de exercício de uma verdadeira razão (crítica), partindo da compreensão das causas pelas quais o ser humano não superou a barbárie. O filósofo afirma que para a superação da barbárie é fundamental o desenvolvimento de uma racionalidade dirigida a uma autorreflexão crítica que vise a permitir que o sujeito, nesse contexto de um mundo administrado, seja capaz de "reconhecer os mecanismos que tornam as pessoas capazes de cometer tais atos" e, além disso, a revelar "tais mecanismos a eles próprios, procurando impedir que se tornem novamente capazes de tais atos, na medida em que se desperta uma consciência geral acerca desses mecanismos" (ADORNO, 1995, p. 121).

Atarefa do pensamentofilosófico críticoéarticulada em complementaridade ao papel da obra de obra. Para escapar dos tentáculos da sociedade administrada, especialmente na sua forma de indústria cultural, e cumprir com o seu papel de crítica social, restaria à verdadeira obra de obra de arte resistir à lógica de identidade da produção cultural na sociedade. Isso se manifestaria, inclusive, na sua forma de apresentação, a qual deveria ser enigmática. A obra de arte deveria representar um enigma a ser decifrado mediante um autêntico exercício racional (atividade que caberia à crítica filosófica) para não se deixar capturar pela lógica de identidade, de fácil consumo, de apropriação e contextualização imediata. E, nesse aspecto, a literatura kafkiana é o exemplo ideal que despertará o interesse filosófico de Adorno.

\section{Obra de arte, dialética negativa e verdade}

Filosofia e obra de arte se aproximam e se complementam enquanto crítica e resistência à aparente ordem sociedade administrada, mas não são o mesmo. Adorno entende como fundamental à arte o papel de protesto, exigindo que ela demonstre abertura para a autorreflexão e o diálogo com indivíduos autenticamente racionais. A definição de obra de arte é pensada através de sua historicidade (não no sentido de uma continuidade, pois, como afirmamos, a história não é entendida como linear pelo filósofo), mas enquanto ruptura com a ordem vigente de uma sociedade administrada. A arte é heteronomia pelo seu caráter social; contudo, é autonomia, pois resiste e se diferencia da realidade, negando as atividades humanas alienadas e administradas.

A arte, portanto, retira o seu conteúdo ao negar o social do qual ela faz parte de alguma maneira, funcionando, em última análise, como um encontro entre o objetivo e o subjetivo, contendo verdade para ser decifrada pelo sujeito. Nesse sentido, Adorno vai argumentar que a satisfação que a arte 
pode proporcionar vai no sentido de eliminar o véu que paira sobre nossa individualidade concreta, reprimida e abafada pelo esforço individual de inserção na sociedade.

\begin{abstract}
“O conceito de gênio é falso, porque as obras não são criações e os homens criadores" - a obra aparece, enquanto obra, como autonomia "heterônoma" em relação a quem leva o título de seu autor: "Ao final, o escritor não poderá nem mais habitar em seus escritos..." Isso porque a "experiência da arte enquanto experiência de sua verdade ou inverdade é mais do que uma vivência subjetiva: é a irrupção da objetividade na consciência subjetiva. (SOUZA, 2004, p. 104).
\end{abstract}

Em decorrência do referido tensionamento dialético de afirmação e negação do e no todo social, entre objetividade e subjetividade, a obra de arte seria uma forma privilegiada de representação da realidade.

A obra de arte é entendida como uma aproximação aberta à realidade, demandando o estabelecimento de uma relação dialética com o sujeito. Convocando o sujeito para o exercício de uma atividade verdadeiramente racional com a obra, representando uma forma de aproximação distinta da solução iluminista de representação idealista do mundo por meio de conceitos fechados, que teria a pretensão de espelhar a realidade. Diferentemente da relação de imediata absorção das mensagens simplificadas de uma produção da indústria cultural (onde não há o que ser interpretado, toda a mensagem é imediatamente revelada), a relação com uma verdadeira produção artística deveria ser fundamentada no espaço para a interação e interpretação de seu significado, que, por sua vez, deveria ser fruto do referido movimento crítico dialético de inserção/negação na sociedade.

Importante esclarecer o entendimento de Adorno com relação aos termos dialética e dialética negativa. De acordo com o filósofo dialética negativa é tautologia, conforme afirmado explicitamente em sua obra Dialética negativa (2009).

Por outro ângulo, pode-se dizer também que o pensamento de Adorno, bem como o de outros membros da Escola de Frankfurt, tinha na dialética sua referência metodológica principal. Mas de que dialética se trata? Exatamente na dialética negativa, a expressão dessa ousadia uma petitio principii. Isto porque, para Adorno, a única "dialética" que se poderia considerar como propriamente tal seria aquela aberta, irredutível a uma "resolução" superior, negativa em relação à positividade da totalidade ao fim das contas autossuficiente, quando por "totalidade" se entende pretensão de verdade que a falsa consciência - a consciência incompleta ou falseada de 
si mesma e da realidade - institui como verdade suficiente. (SOUZA, 2004, p. 98).

Com efeito, a origem etimológica da palavra dialética conduz a uma ideia de diálogo, debate, discussão ${ }^{2}$. Cogitar a possibilidade de uma dialética positiva seria negar o fato de que o estabelecimento da dialética não prescinde do elemento dual. Diante das estruturas racionais apresentadas como mera repetição, aproximando-se ao mito, o trabalho dialético necessariamente deve ser negativo: uma resistência da verdadeira razão ancorada na realidade contra a opacidade da racionalidade já pensada.

Pensar é, já em si, antes de todo e qualquer conteúdo particular, negar, é resistir ao que lhe é imposto; o pensamento herdou esse traço da relação do trabalho com seu material, com seu arquétipo. Se hoje mais do que nunca a ideologia incita o pensamento à positividade, ela registra astutamente o fato de que justamente essa positividade é contrária ao pensamento e de que se carece do encorajamento amistoso da autoridade social para habituá-lo à positividade. (ADORNO, 2009, p. 25).

A racionalidade do homem é uma qualidade que só se sustenta pelo constante exercício crítico, tão inacabado quanto a própria humanidade do ser humano, sempre a (se) construir. Razão já pensada é repetição automática e não racionalidade crítica. Repetição é a maneira pela qual todos os mitos têm se conservado na consciência coletiva.

Pensar é ter rumos, tomando consciência desses rumos. Os objetos resistem mais à objetificação do que uma certa lógica racionalista idealizante muito poderosa nos acostumou a conceber. Mas aqui dizemos os objetos eles mesmos, e não suas "essências", nomes ou algo, como diria Rosenzweig, completamente diferente deles mesmos, que a racionalidade instrumental é capaz de conceber como sendo "propriamente" eles mesmos. Por outro lado, pensar é ir, necessariamente, além do pensamento. O pensamento não destila realidades, mesmo o pensamento crítico. O pensamento filosófico indica realidade com uma propriedade que a falsa consciência do mundo é incapaz de anular, por mais que a substitua por sucedâneos mais brilhantes e atrativos, ou mais coloridos e fáceis. Ali onde o pensamento se dá, é onde a angústia da diferença se torna inamovível. Inamovível, mas não paralisada: o pensamento, no estreito fio de navalha no qual é obrigado a se mover para não cair, nem na banalidade, nem na violência e na perversão, pode contar com ela para permanecer

2 O termo dialética, de origem grega, é composto de dia (troca através de) e lekticós (apto à palavra) e tem a mesma raiz de diálogo: troca de palavras. 
em si mesmo sem se fechar em si mesmo. (SOUZA, 2004, p. 124-125).

A partir disso, o pensamento filosófico adorniano recusa toda e qualquer filosofia que se cristalize em ontologia positivista/idealista. Adorno constrói uma espécie de ontologia negativa, se podemos assim chamar, fundamentada na presença em tempo integral do sofrimento na história da humanidade. Portanto não se trataria de uma doutrina de afirmação do ser, mas de uma negatividade sempre presente na civilização, tal qual ele compreende que Kafka procede em sua obra.

Em vez de curar a neurose, ele procura nela mesma a força que cura, a força do conhecimento: os estigmas com que a sociedade marca o indivíduo são interpretados como indícios da inverdade social, são lidos como o negativo da verdade. A força de Kafka é a da demolição. Diante do sofrimento incomensurável, ele derruba a fachada acolhedora, cada vez mais submetida ao controle racional. (ADORNO, 1998, p. 247).

Partindo da necessidade da existência do movimento dialético para se falar em racionalidade, Adorno compreende o nascimento da obra de arte motivado e fundamentado na percepção do sofrimento gerado a partir do suposto progresso da humanidade prometido pela razão iluminista. Na percepção do movimento progresso e sofrimento que se faz possível o estabelecimento da relação ambivalente/dialética, chegando a afirmar em sua Teoria Estética (1970) "Mas que seria a arte enquanto historiografia, se ela se desembaraçasse da memória do sofrimento acumulado?" (ADORNO, 1970, p. 291).

Graças a esse caráter ambivalente, a obra de arte se apresenta como abertura para um diálogo, para o estabelecimento de uma relação dialética. Ela não se afirma ao sujeito. A manifestação artística representa o diferente que introduz a diferença na sociedade massificada, administrada e repetidora de padrões artísticos por meio da indústria cultural. E, nessa tarefa, conta com a filosofia enquanto sua chave interpretativa, evidenciando-se a relação entre ambas: "Por um lado, estética é teoria filosófica e, portanto, alheia à arte. Por outro lado, há necessidade de uma reflexão filosófica. Obras de arte são formas objetivas e têm em si a pretensão de objetivar-se; nessa decifração, o enigma revela seu conteúdo de verdade" (SCHULZ, apud ROSA, 2007, p. 97).

Caberia à filosofia, portanto, interpretar a obra de arte para "dizer o que ela não consegue dizer, mas que só por ela "pode ser dito, ao não dizê-lo"" (PUCCI, 1997, p. 170). Para Adorno, pela crítica filosófica respeitadora do fenômeno artístico, seria possível extrair o conteúdo de verdade da arte. 
A arte verdadeiramente contradiz a lógica da totalização, porque é expressão da verdade do diferente que não se reduz ao "mesmo": "Só compreende uma obra de arte aquele que a compreende como complexão de verdade"... "a missão da arte hoje é introduzir o caos na ordem.” (SOUZA, 2004, p. 101).

Contudo, tal processo de interpretação não seria estanque, sob pena de cair na mesma armadilha apontada com relação às filosofias idealistas; ele poderia ser repetido diante da multiplicidade de significados presentes nas obras graças ao seu caráter enigmático, que deve ser decifrado. Tal aproximação à verdade seria possível, conforme afirmado, pois a arte resistiria à lógica totalizante identificadora da racionalidade instrumental, repetidora das inverdades que servem de fundamento e manutenção da sociedade administrada. Ao resistir, a arte seria a possibilidade de manifestação da verdade.

\begin{abstract}
Aarte é, para Adorno, uma instância da verdade que, em princípio e por definição, se situa para além de toda possibilidade da ideologia que a quer manietar (poderíamos acrescentar que é por isso que a música, por exemplo, é cercada geralmente de um aparato formal, quando de sua execução pública: esta é uma tentativa de mantê-la dentro dos limites de uma determinada "aceitabilidade" ideológica). Por isso, também, a arte só é "interpretável pela lei de seu movimento, não por invariantes" (Teoria estética, p. 13). E sua verdade não advém de um sentido que um sujeito lhe possa atribuir, pois isso seria sua própria falência... (SOUZA, 1996, p. 49).
\end{abstract}

Conforme referido, Adorno afirma que a verdadeira obra de arte, diferentemente do falso prazer (satisfação enquanto mero entretenimento) que é fornecido pela indústria cultural, expressa o sofrimento humano em seu cotidiano para sobreviver em uma sociedade sufocantemente administrada. Os seres humanos são obrigados a reprimir uma parte de sua vida (desejos, ambições, sonhos, ideais, etc) para viverem sob a administração da razão instrumentalizada posta a serviço da lógica burguesa de mercado.

\footnotetext{
Kafka peca contra uma tradicional regra do jogo ao produzir arte exclusivamente a partir do que é recusado pela realidade. A imagem da sociedade vindoura não é esboçada imediatamente - pois Kafka, assim como todo grande artista, se comporta asceticamente diante do futuro -, mas montada a partir do entulho que o novo, em processo de formação, elimina do presente que se torna passado. (ADORNO, 1998, p. 89).
}

Assim, enquanto os produtos da indústria cultural são mercadorias geradas sob o mesmo signo da identidade que não demandam interpretação 
e não possibilitam relação verdadeiramente racional, na genuína obra de arte o ser humano é livre para pensar, sentir e agir, servindo, dessa forma, como possibilidade de libertação do homem das amarras do sistema.

Portanto, de todo o argumentado, Adorno afirma que o objetivo principal da filosofia em relação à arte, que não pode ser comprometida com a racionalidade instrumental, é o de interpretar seu conteúdo de verdade, assumindo uma atitude crítica com relação à indústria cultural, e aos tentáculos de uma sociedade totalmente administrada, permitindo ao indivíduo sua libertação; em última análise, sua humanização.

\section{Adorno e Kafka}

Conforme referido, a filosofia de Adorno é marcada pela crítica ao projeto de desencatamento do mundo que, baseado na racionalidade instrumental, se converteu em dominação da natureza e do próprio ser humano. A razão que desencantou o mundo e livrou o humano do mito caiu novamente em uma compreensão mitológica ao deixar de realizar a sua própria autocrítica. A razão fechada em conceitos repetidos à exaustão e aplicada irrestritamente para as mais diversas finalidades se torna reificada, transformando-se em mero instrumento a serviço dos ideais burgueses.

Podemos dizer que Kafka é um dos primeiros intelectuais a escrever sobre a relação entre progresso, entendido enquanto desencantamento da natureza pela razão iluminista, e dominação violenta do ser humano (barbárie). Tal qual teorizado anos mais tarde por Adorno e acima explicitado, a obra kafkiana é marcada por personagens que oscilam nebulosamente entre o humano e o animal (a obra A metamorfose, 1977, pode ser apontada como o exemplo mais claro nesse sentido). Kafka evidencia a vida nua diante de uma realidade exterior opressora, altamente burocratizada, sufocante, incompreensível, marcada por uma indiferenciação entre o espaço público e o privado (como se vê, por exemplo, em O processo, 1976).

Nesse sentido, pensamos que a obra $A$ toca (KAFKA, 1931) seja uma alegoria central para que se compreenda a visão que Kafka tem desse ser humano do iluminismo, que fracassa na tentativa de se afirmar pela razão, tornando-se refém de sua própria criação. Em referido conto, um animal roedor constrói para si um refúgio, pretendendo proteger-se; contudo, esse mesmo abrigo, de tão seguro, converte-se em uma armadilha para o seu próprio construtor. Como na filosofia de Adorno, na qual o ser humano que seria libertado da natureza pela razão se converte em vítima de seu elemento de libertação. Kafka ilustra literariamente essa armadilha da razão enquanto Adorno a contextualiza, interpreta e analisa filosoficamente. 
Para empreender essa crítica artística à instrumentalização da razão, a representação da sociedade em Kafka apresenta dois tipos principais de personagens: um, despido de qualquer exercício crítico racional próprio, apenas repetidor de uma racionalidade (instrumental) externa que já pensou tudo por ele, aproximando-se ao animal, e outro, que é apresentado como vítima da violência/dominação exercida pelo primeiro, enquanto representante da sociedade administrada. Com relação ao segundo tipo, Adorno afirma que "Como o caçula nos contos de fada, a pessoa deve tornarse discreta e pequena, uma vítima indefesa que não insiste no seu direito, segundo os costumes do mundo que reproduz ininterruptamente a injustiça" (ADORNO, 1998, p. 268).

O seguinte trecho de $O$ processo parece ter sido criado para servir de exemplo às densas linhas traçadas por Adorno sobre a animalização do ser humano e a sua submissão à racionalidade instrumental regida pelos interesses burgueses:

\begin{abstract}
Nós somos apenas funcionários subalternos, que pouco ou nada percebem de documentos de identificação e que, neste caso, não têm outra missão a não ser a de vigiá-lo dez horas por dia. É para isso que nos pagam. No entanto, ainda somos capazes de compreender que as altas autoridades, ao serviço das quais estamos, antes de darem uma ordem de prisão, tiram minuciosas informações acerca da pessoa a ser detida e dos motivos da detenção... Assim, não há possibilidades de engano. As nossas autoridades, até onde eu conheço, e os meus conhecimentos não vão além das categorias mais baixas, não são daquelas que andam atrás das culpas das pessoas, mas, como diz a Lei, são forçadas pelos delitos a enviarem-nos a nós, os guardas. É assim a Lei. Como poderá haver enganos? (KAFKA, 1976, p. 14).
\end{abstract}

A fragilidade racional dos guardas é evidenciada por sua insegurança representada genialmente por Kafka nas idas e vindas de sua argumentação (mesmo subalternos, os guardas são capazes de entender que a ordem de prisão foi precedida de uma análise minuciosa das autoridades superiores; e essas autoridades, de novo, no limite da compreensão de meros guardas, são movidas pela lei). A postura dos guardas encontra comentário e interpretação em Adorno: "Figuras subalternas como os sargentos, colaboradores e porteiros exercem uma violência desenfreada. São todos desclassificados que, na queda, foram amparados pela coletividade organizada e tiveram permissão para sobreviver..." (1998, p. 256).

Outro aspecto abordado em Kafka, retrato fiel da sociedade administrada, é a burocracia enquanto peça chave para o funcionamento de toda a engrenagem. 
Conduzida para um desiderato escamoteado, baseada na divisão das tarefas e das informações que não permite ao executor da ordem a possibilidade de reflexão; basta-lhe a execução técnica do que foi determinado.

A burocracia é entendida para, basicamente, duas necessidades: pulverização da violência, que se dá de maneira mais eficiente e impercepvível, e como mecanismo para evitar o choque direto entre os dominados e dominadores, interpondo classes intermediárias entre eles. Com relação à dominação violenta, mesmo diante da violência da tarefa que lhes cabe, os funcionários pouco sabem sobre todo o processo; em verdade, eles sabem apenas o necessário para realizar o seu ofício. No tocante à hierarquia pensada para servir de elemento para aliviar a tensão entre classes, na obra Prismas (1998), Adorno promove uma interessante ligação de Kafka com Freud para melhor explicitar esse mecanismo:

\begin{abstract}
A concepção de hierarquia não difere muito em Kafka e em Freud. Em uma passagem de Totem e tabu, Freud afirma que "o tabu de um rei é tão forte para seus súditos porque a diferença social entre eles é enorme. Mas um ministro talvez possa ser um mediador inofensivo entre ambos. Traduzido no linguajar do tabu para a linguagem normal, isso significa: o súdito, que teme a enorme tentação envolvida no contato com o rei, pode eventualmente tolerar o relacionamento como um funcionário que ele não precisa invejar tanto, e cuja posição pode até mesmo parecer estar a seu alcance. O ministro, por sua vez, pode contrabalançar sua inveja do rei pela consideração do poder que lhe foi concedido. Portanto, pequenas diferenças nas forças mágicas que levam à tentação causam menos temor do que as enormes" (ADORNO, 1998, p. 245-246).
\end{abstract}

A obra de Kafka é um retrato da vida na contemporaneidade. Não apenas da burocracia que movimenta o direito na obra $O$ processo, mas da burocracia que marca todas as grandes organizações, onde a informação é dividida de tal maneira que parece não existir de fato após promovida a soma de todas as suas pequenas partes espalhadas por cada um de seus técnicos/especialistas. Algo como um atendente de qualquer uma dessas companhias de telefonia que possui a exata quantidade de informações suficientes para irritar o cliente e depois repassar a ligação para outro técnico com a mesma vocação. A razão de ser habita tão-somente a cabeça de quem concebeu o procedimento juntamente com o seu verdadeiro objetivo.

Na ilustração da obra O processo qualquer possibilidade de estabelecimento de uma relação materialmente dialética é completamente substituída pela imposição violenta da razão instrumentalizada, representada pela certeza e pela necessidade de sua imposição a qualquer custo. Há um choque violento 
entre a certeza inequívoca dos guardas e a completa falta de informação do acusado sobre os motivos da acusação. Importante frisar que a certeza é do sistema (da sociedade administrada, diria Adorno), mas que nenhum dos diretamente envolvidos, de fato, conhece. Isso se deve, como já argumentado, à pesada burocracia e à sua inerente especialização de tarefas (ao excesso de racionalidade já pensada que cristaliza o exercício racional dos sujeitos).

Esse excesso de razão, enquanto pesada burocracia, contrasta com a esperança ingênua de K (o acusado do processo kafkiano) na declaração de sua inocência. Ingênua, pois ele, também, de certa forma, confia no sistema que o está acusando: "As poucas palavras que eu trocar com alguma pessoa do meu nível tornarão tudo incomparavelmente mais claro do que as conversas mais longas com estes homens" (KAFKA, 1976, p. 13). As conversas que K mantém com os guardas não são capazes de clarear os fatos, pois, em verdade, sequer podem ser chamadas de conversas. Os argumentos de $\mathrm{K}$ nunca são diretamente respondidos; eles são, um a um, apenas barrados por afirmações, produtos de uma racionalidade que afirma e que não está aberta para o estabelecimento da relação, da conversa, do real diálogo. A racionalidade insistentemente repetida perde seu estatuto racional dialético transformandose em mera crença.

\footnotetext{
Na obra kafkiana, a razão anestesiada por si mesma onipresente impede a prática da "crítica" no seu sentido tradicional. No mundo dos personagens de Kafka - como para o herói das epopéias com sua astúcia - não existe crítica, mas apenas a racionalização das perdas e ganhos. Como Benjamin observou com uma pitada de ironia, "de todos os seres de Kafka, são os animais os que mais refletem". O leitor é conclamado a julgar a sociedade tal como ela é refletida e revelada em seus textos. $\mathrm{O}$ escândalo da ausência de crítica pode, eventualmente, gerar no leitor uma reflexão sobre a sua própria situação. Como escreveu Adorno, "em Kafka, o fato de a forma ser o lugar do conteúdo social deve ser concretizado na linguagem" (SELIGMANNSILVA, 2009, p. 123).
}

Justamente, por detrás dessa falta de diálogo (como é possível conversar com quem já decorou todas as respostas?), se esconde a dominação e a violência necessárias para perpetuar o controle. Essas pequenas doses de violência, que atingem obviamente também os atendentes e que a maioria das pessoas sequer tem a sensibilidade de senti-las como violência, escamoteiam um astuto mecanismo de manutenção da situação vigente.

Especialmente em O processo e na Colônia penal (1998), os funcionários da burocracia alertam para outro aspecto da obra kafkiana: o encantamento pelo sistema. Eles se mostram encantados pela beleza e pela perfeição do projeto 
que defendem (mesmo sem entenderem ao certo a razão de tal admiração). Aspecto igualmente capturado e teorizado filosoficamente por Adorno quando se refere à admiração das vítimas da violência com os seus algozes.

A massa controlada na contemporaneidade crê nos produtos da racionalidade instrumental, que se apresentam muito mais como mitos, consagrados pela repetição, do que como resultados de um autêntico exercício racional. A crença no mito dos produtos da razão já pensada deriva de uma relação de conveniência. Desde muito cedo a postura crítica é reprimida na sociedade administrada. Quem se comporta como a massa é recompensado pela inclusão no sistema e pela facilitação do pensamento. Como diz Adorno, o doloroso processo dialético é poupado.

\section{Considerações finais}

Tendo como ponto de partida a relação dialética estabelecida entre progresso e barbárie, Adorno procurou ir além da obviedade (ainda constantemente afirmada) de que a barbárie seria produto apenas de irracionalidade. Isso se fez possível mediante uma consistente crítica aos sistemas idealistas tradicionais, demonstrando o caminho que a filosofia idealista percorreu para ser tornar fundamento para uma razão totalizadora, dominadora da natureza e produtora de barbárie.

Para dar conta de tão pesada tarefa, Adorno compreendeu que, assim como a filosofia não poderia se constituir à base da identidade pretendendo abarcar a totalidade da realidade, sob pena de se tornar mera ideologia, a arte não poderia ser um instrumento de repetição dessa lógica. Com essa ideia muito presente, Adorno apontou a genuína manifestação artística como sendo possibilidade de resistência a essa falsa ordem; o elemento que inseriria o necessário caos nessa ordem. Resistindo, a arte abrigaria por detrás de seu caráter enigmático seu caráter de verdade, seria como um refúgio da verdade que não poderia ser dita pela linguagem da sociedade controlada. A obra de arte representaria a inserção do caos da verdade na ordem identificadora repetidoras de inverdades.

Justamente essa forma enigmática de manifestação artística, eleita por Kafka, dificultou durante muito tempo uma compreensão mais completa da potencialidade crítica de sua obra. Seus contos, que poderiam parecer mera ficção numa análise apressada, foram se consolidando cada vez mais pelo seu excesso de realidade ao longo do tempo. Na mesma medida em que a representação conceitual da realidade foi levantando suspeitas sobre a sua possibilidade de correspondência e prestabilidade absoluta enquanto motor da civilização. 
Primado do objeto e realismo estético opõem-se hoje quase que contraditoriamente, e isto seguindo um critério realista: Beckett é mais realista que os realistas socialistas, os quais, em seu princípio, falsificam a realidade. Se estes a [à realidade] tomassem suficientemente a sério, se aproximariam do que Lukács condena, ele que, durante sua prisão na Romênia, teria dito que agora sabia que Kafka era um escritor realista. (ADORNO apud ROSA, 2007, p. 110).

A resistência ao todo social administrado seria observada pela forma de enigma e pelo conteúdo de verdade revelado após a sua interpretação. A verdadeira manifestação artística em Adorno deve ser pensada por um indivíduo emancipado, com capacidade racional para além das obviedades identificadoras repetidas pela razão instrumental. Para tanto, o artista deve ter a capacidade de compreender a lógica de identidade da sociedade administrada, situando a obra no contexto histórico, econômico e social, atribuindo, assim, sentido à produção artística.

Adorno, dialeticamente, critica, analisa e interpreta a obra de Kafka, expondo as suas entranhas; revelando o que Kafka, provavelmente, pretendia dizer, mas, se o fizesse, deixaria de ser arte. Assim, por todo o argumentado, entendemos que a relação que Theodor Adorno estabelece entre filosofia e obra de arte é representada pela tarefa que aquela tem de interpretar essa.

$\mathrm{O}$ encadeamento proposto no presente artigo foi defendido a partir da relação entre o filósofo e músico que, graças à sua mente artística, foi capaz de perceber que a filosofia, para merecer a denominação de atividade racional, deve ininterruptamente autocriticar-se, sob pena de transformar-se em ideologia, com o escritor que, por sua mente maltratada pela repetição da razão reificada enquanto advogado de uma companhia de seguros, mostrou de maneira sutil (dizendo sem dizer) as patologias extremas de um mundo despido de uma atividade racional crítica.

\section{Referências}

ADORNO, T. W. Educação e emancipação. Rio de Janeiro: Paz e Terra, 1995.

ADORNO, T. W. Dialética Negativa. Rio de Janeiro: Zahar, 2009.

ADORNO, T. W. Minima moralia. São Paulo: Ática, 1993.

ADORNO, T. W. Prismas. São Paulo: Ática, 1998.

ADORNO, T. W. Teoria estética. Lisboa: Edições 70, 1970. 
ADORNO, T. W.; HORKHEIMER, M. Dialética do Esclarecimento. Rio de Janeiro: Zahar, 1985.

KAFKA, F. A toca. In: A muralha da China. São Paulo: Nova Época, [19--], p. 41-72.

KAFKA, F. A metamorfose. CARONE, Modesto (trad.). São Paulo: Companhia das Letras, 1977.

KAFKA, F. O processo. ÁLVARO, Gervásio (Trad.). Lisboa: Círculo de Leitores, 1976.

KAFKA, F. O veredicto / Na colônia penal. CARONE, Modesto (Trad.). São Paulo: Cia das Letras, 1998.

PUCCI, B. Filosofia negativa e educação: Adorno. Filosofia, sociedade e educacao (UNESP), Marilia, v. 1, n. 1, p. 163-192, 1997.

ROSA, R. Catarse e resistência: Adorno e os limites da obra de arte crítica na pós-modernidade. Canoas, RS: Editora da Ulbra, 2007.

SELIGMANN-SILVA, M. A atualidade de Walter Benjamin e de Theodor W. Adorno. Rio de Janeiro: Civilização Brasileira, 2009.

SOUZA, R. T. Totalidade \& Desagregação - sobre as fronteiras do pensamento e suas alternativas. Porto Alegre: EDIPUCRS, 1996.

SOUZA, R. T. Razões plurais - Itinerários da racionalidade ética no século XX. Porto Alegre: EDIPUCRS, 2004.

Submissão em: 13/03/2015

Revisão em: 20/09/2015

Aceite em: 17/11/2015

\section{Agência de fomento: CAPES - Bolsa PROSUP.}

Pedro Savi Neto é professor de Filosofia da Educação do Curso de Pedagogia da Pontifícia Universidade Católica do Rio Grande do Sul (PUCRS). Professor de Ética da Especialização em Gestão da Educação da PUCRS. Mestre em Filosofia, na área de Ética e Filosofia Política, e Doutorando em Filosofia da Educação pela PUCRS. Endereço: PPG em Filosofia da Educação/PUCRS. Av. Ipiranga, 6681. Prédio 5 Sala 608. Porto Alegre/RS, Brasil. CEP 90619-900 E-mail:p.savi@hotmail.com 